\title{
IIRTBT A STUDY ON PROPENSITY TOWARDS VARIOUS INVESTMENTS OPTIONS
}

\author{
Yash Sharma $^{1 *}$ \& Kausik Mukherjee ${ }^{2}$ \\ ${ }^{1}$ Madhav Complex, Sindhi Camp, Satna, Madhya Pradesh, India \\ ${ }^{2}$ Management Studies, AKS University Satna, Madhya Pradesh, India \\ *Corresponding Author's E-Mail: yashd.sharma113@gmail.com
}

\begin{abstract}
Investment planning for a person who aspires safe and steady return is simple, but the thought process, in general, makes it difficult and less effective. In general, it seems that people have a perception that only a fixed deposit can give a fixed and constant return, but that is just a myth, because if we put the money into different buckets like FD, mutual funds, and stocks, then also we can get safe and steady returns.
\end{abstract}

\section{Keywords: Investment Strategy; Investment Planning; Investment Inclination; Investment Perception}

\section{INTRODUCTION}

Investment is when we put our $\mathrm{X}$ amount of money in any kind of financial or non-financial asset to get $X$ plus a certain percentage of return. Mostly in the case of financial instruments, people invest in FD (Fixed Deposit), LIC (Life Insurance Company), Mutual Fund, PPF (Public Provident Fund), NPS (National Pension Scheme), Post office or Stock Market.

Generally, people feel comfortable in investments like FD, LIC, PPF, NPS, etc. Very few people take interest in mutual funds and a negligible number of people take interest in the share market. The reason behind this is that most of the people have in their back of mind that FD, PPF, etc. investments are safe and gives a moderate return (Barber \& Odean, 2008).

Under this study, we will analyze the return of different investments like FD, mutual fund and share market and try to understand the best investment avenues according to risk and reward. We will also try to break the myth that only FD can give a safe and steady return.

There is a myth about the stocks and mutual funds that these are very risky, and people feel that FD is the only way to get a fix and safe return. So, under this research, we will try to understand that what is the rate of returns under different avenues and can we get safe returns in mutual funds and stocks also (Muniappan \& D. sivasakthi, 2011; Dhawan \& Mehta, 2019).

There is only a lack of knowledge because of which a person does not invest in mutual funds or stock and satisfy himself with less returns. Many people are not aware that in the case of mutual funds also there are many options where the returns are higher as well as safe (Kulal, Alasbahi \& Al-Gamal, 2019).

In the first part of the paper, we will analyze the returns in different avenues, and in the second part of the paper we will analyze the input from data collected from random people, and in the final section we will try to conclude that we can earn a decent return and safe return in any other financial instrument other than FD.

\section{Need \& Implementation}

The main objective of the research is to analyze that which is the best among FD, mutual funds, and stocks based on rate of return and safety. This analysis will break the myth of common people that only FD can give a safe and steady return.

People, who retire, want to keep their retirement fund safe as a return from this fund will be the lifeline for them. People who are working also aspire to make investment planning in such a way that he/she can get a better, safe as well as a fixed return. In our analysis, we will provide the advisory for good investment planning.

\section{RESEARCH METHODOLOGY}

- This research is empirical in nature.

- We will collect the data from secondary sources.

- Sampling universe is all mutual funds, shares and FD.

- Judgment sampling will be used for selection of samples.

- Sample size will be any random mutual funds and any random stocks from NSE and any FD rates.

- Risk free rate will be assumed equal to the bank's FD Rate. 
We had taken the samples of around 25 people just to know that what do they think when it comes to the good returns and safety on money while investing. It can be seen in the below pie chart that $80 \%$ of the people feel that FD gives a very safe and constant return as compared to other financial instruments (refer to figure 1).

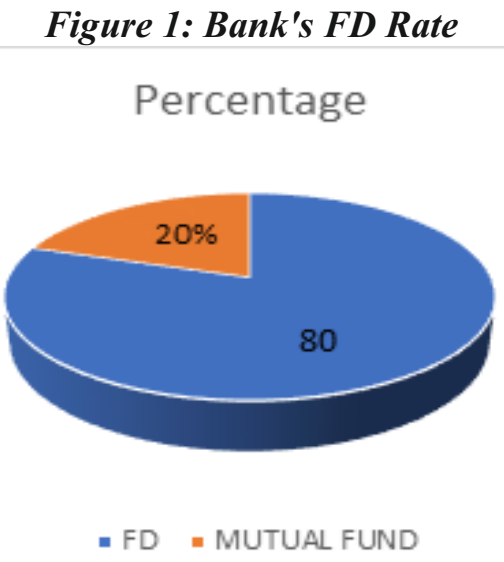

Source: Money Control Application

So, we can say that $80 \%$ is the major population who feels that FD gives safe investment and gives a constant return. Hence, most people, in general, think that FD is the only option to get a constant and safe return but, this is not true. This analysis will show that we may get a constant and very safe return from other instruments also like mutual funds. So primarily we will try to prove in this research paper that people have other portfolios other than FD which gives safe and constant return.

\section{RESULT \& DISCUSSION}

First, we will take random samples of mutual funds in Large Cap, Mid Cap \& Hybrid along with their returns were 1, 2 and 3 represents the years (see below figures 2 to 6 ).

Figure 2: Multi Cap Fund - UTI Flexi Cap Fund - DP (G)

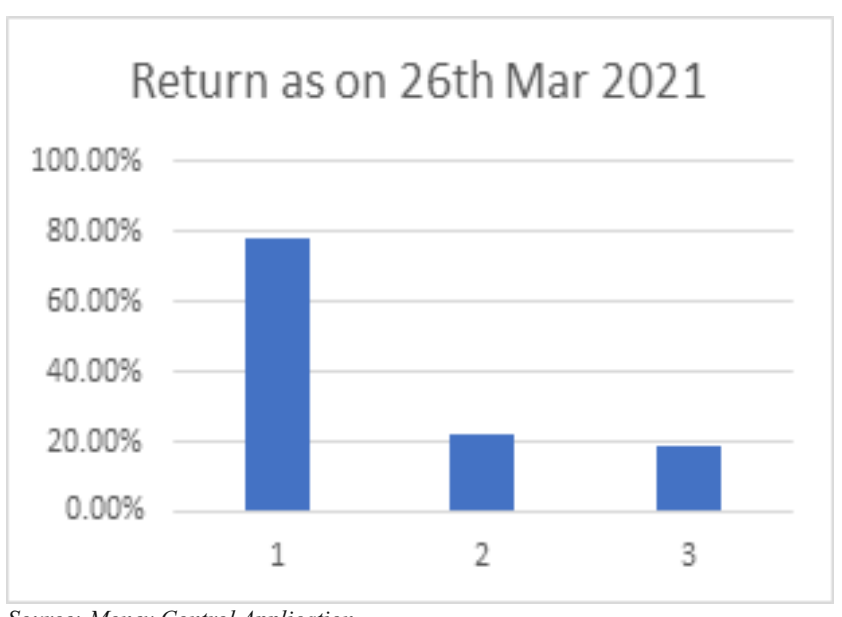

Source: Money Control Application
Figure 3: Large Cap Fund-Axis Blue-Chip Fund-(G)

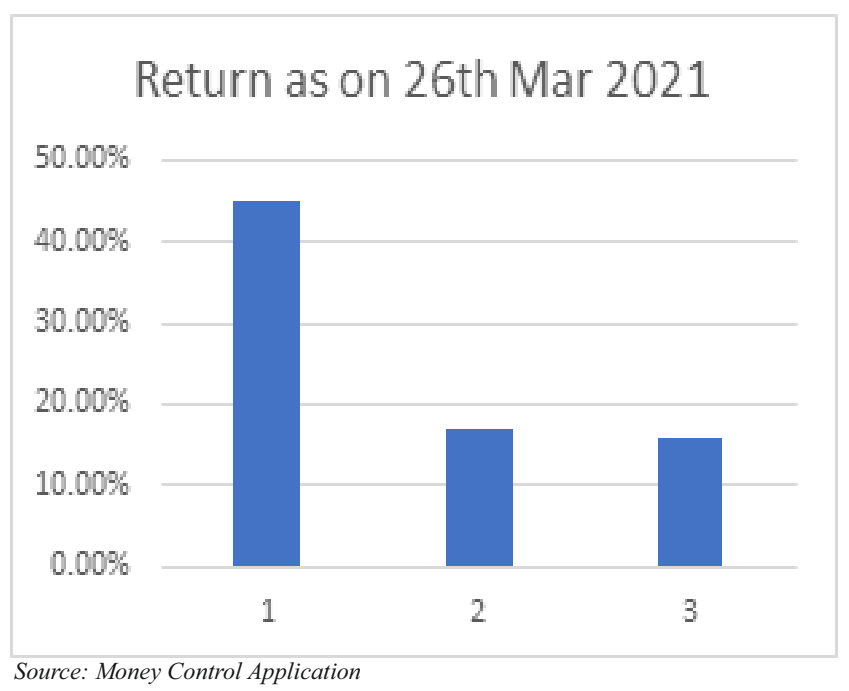

Figure 4: Mid Cap Fund - Axis Mid Cap Fund - (G)

\section{Return as on March 26, 2021}

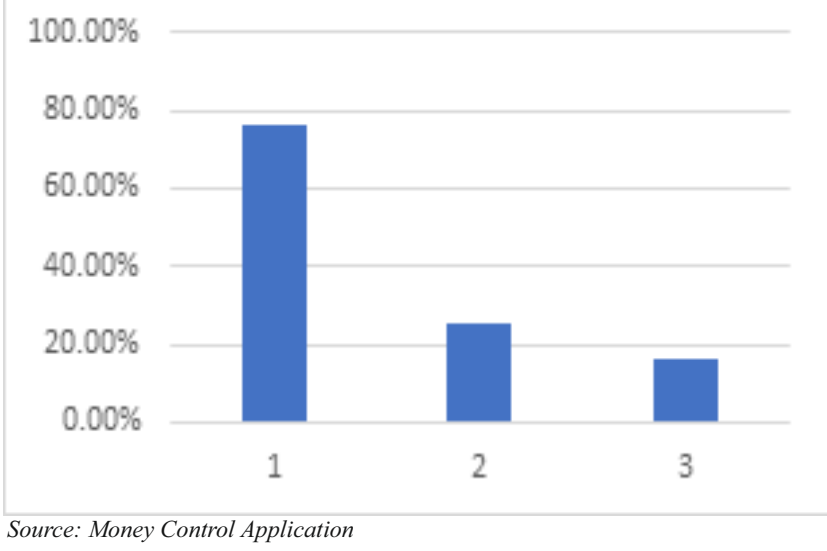

Figure 5: Small Cap Fund - Axis Small Cap Fund G

\section{Return as on 26th Mar 2021}

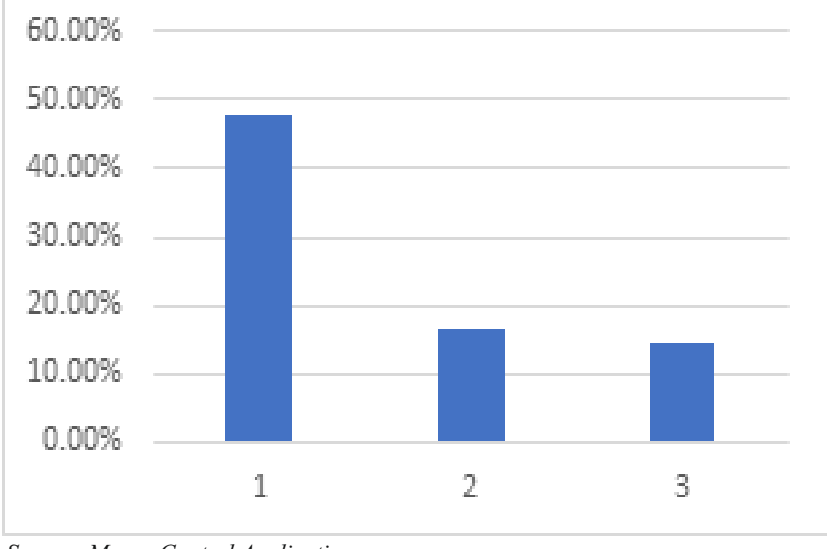

Source: Money Control Application 
Figure 6: Hybrid Fund-CR Equity Hybrid Fund DP-G

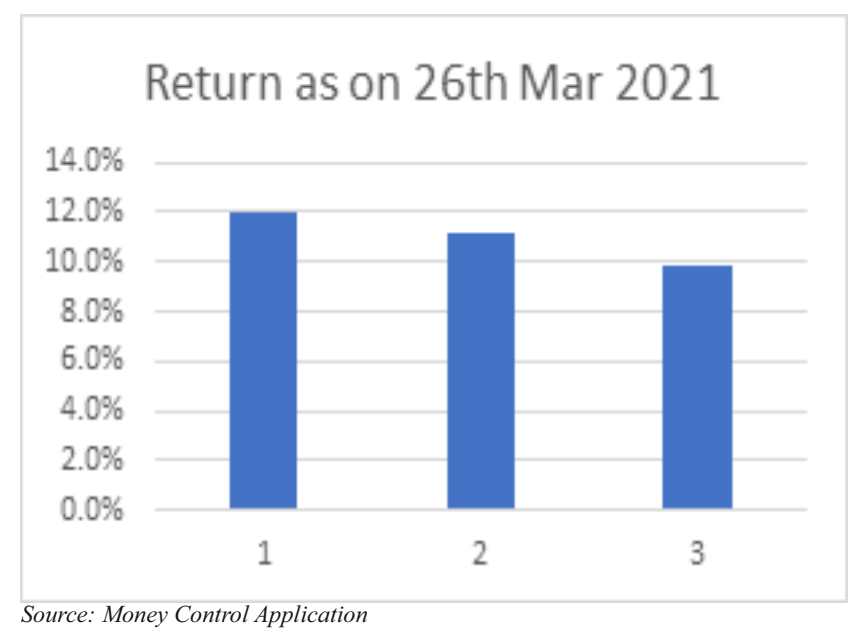

Figure 7: Debt - Edelweiss Bank \& PSU Debt-Reg (G)

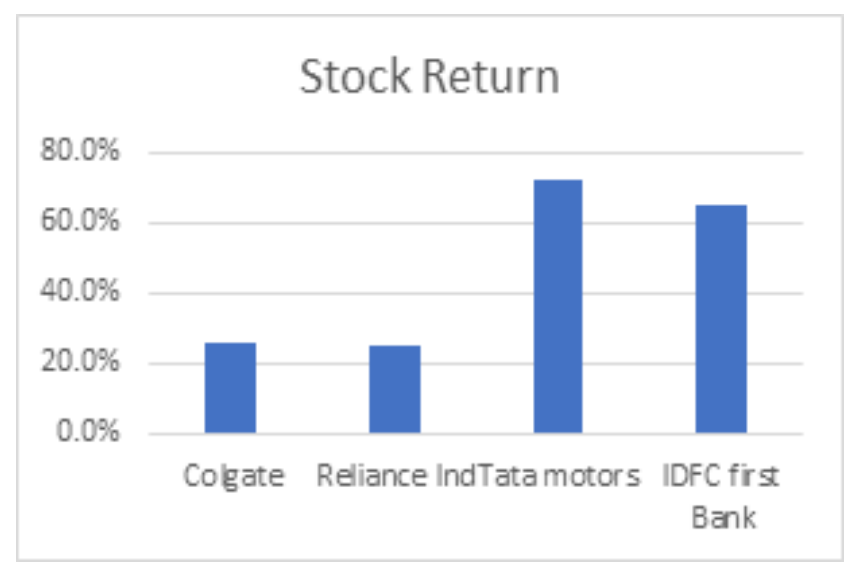

Source: Money Control Application

From the above analysis, we can see that in equity mutual funds the returns are too high, and, in some cases, the return is even more than $40 \%$. In hybrid mutual funds, the returns are between $12 \%$ to $15 \%$. If we look at debt mutual funds, the return ranges between $7 \%$ to $10 \%$. The stocks give returns even more than mutual funds, but the investment is not safe. Even we can say that stocks are the riskiest avenue because there is a possibility that one can lose a big amount of investment. As the stock is not a safe investment, we will not analyze it further. Now we will only talk about mutual funds and Fixed deposits to build a portfolio for a person who desires a decent return along with the safety of investments (Barber \& Odean, 2008; Kulal, Alasbahi \& Al-Gamal, 2019).
So, the first option is to invest the lump sum amount in a hybrid mutual fund and get the dividend income by investing in a dividend scheme and then some portion of the portfolio in fixed deposit so this way you can get an average return of more than approx $10 \%$ which is obviously more than the FD rate.

\section{CONCLUSION}

In case one can take a little risk, then rather than going into stock, the investor can invest a small amount in equity mutual funds. In this way, an investor can get a return with the safety of invested amount.

Thus, this analysis will change the perception of people in general that only investment in FD is safe and will give constant returns. There are more ways like investing in mutual funds which are safe and will give constant and better returns as compared to FD.

\section{Conflict of Interests}

The authors declare that they have no conflict of interests.

\section{ACKNOWLEDGEMENT}

The authors are thankful to the institutional authority for completion of the work.

\section{REFERENCES}

Barber, B.M. \& Odean, T. (2008). All That Glitters: The Effect of Attention and News on the Buying Behavior of Individual and Institutional Investors. The Review of Financial Studies, 21(2), 785-818.

Kulal, A., Alasbahi, A. \& Al-Gamal, E. (2019). Analysis of Investment Pattern of Different Class of People: A Review. Journal of Social Welfare and Management, 11(2), 135-140.

Muniappan, N. \& D. sivasakthi, D. (2011). A Study on Investment Pattern with Special Reference to Small and Medium Capitalization Companies (for Way2wealth Securities (Pvt) Ltd, Coimbatore). Indian Journal of Applied Research, 3(9), 71-73.

Dhawan, D. \& Mehta, S.K. (2019). Saving and Investment Pattern: Assessment and Prospects. ACRN Journal of Finance and Risk Perspectives, 8(1), 123-132. 